\title{
Pulmonary Ventilation-Perfusion Relations after Heart Valve Replacement or Repair in Man*
}

\author{
J. Hedley-Whyte, $†$ H. Corning, $\ddagger$ M. B. Laver, W. G. Austen, and \\ H. H. BENDIXEN \\ (From the Anaesthesia Laboratory of the Harvard Medical School at the Massachusetts \\ General Hospital, the Department of Surgery, Harvard Medical School, and \\ the General Surgical Services, the Massachusetts General Hospital, \\ Boston, Mass.)
}

Decreased oxygenation of arterial blood has been recognized as a postoperative complication of major surgery since the report in 1943 by Maier and Cournand (1). Subsequent studies confirmed their finding by demonstrating low arterial oxygen saturation or tension, particularly after thoracic and cardiac surgery $(2-6)$. These findings suggest increased physiologic shunting (or intrapulmonary venous admixture to arterial blood) as a cause for postoperative hypoxemia.

The use of extracorporeal circulation in cardiac surgery has led to such considerable problems of ventilation and oxygenation $(5,7-9)$ that specific lung damage is conjectured as a consequence of cardiopulmonary bypass $(7,8,10)$.

The physiologic (or total) shunt is that part of the right heart output which does not participate in blood-gas exchange, but is returned unoxygenated to the left heart. The four causes recognized as contributing to the total shunt are the anatomical shunt, a diffusing gradient, uneven distribution of ventilation in relation to perfusion, and atelectasis (11).

The anatomical shunt through bronchial, pleural, and Thebesian veins constitutes approximately $2 \%{ }^{1}$ of cardiac output (13). A diffusing gradi-

* Submitted for publication July 27, 1964; accepted November 19, 1964.

Supported by U. S. Public Health Service research grants HE-08558-02, HE-08043-01, HE-06848-03, and HE-06664 (HEPP) from the National Heart Institute.

† Address requests for reprints to: Dr. John HedleyWhyte, Department of Anaesthesia, Massachusetts General Hospital, Boston, Mass. 02114.

$\ddagger$ Present address: St. George's Hospital Medical School, Hyde Park Corner, London, England.

1 The anatomical shunt may be larger than $2 \%$ in certain diseased states (12). An anatomic shunt of $2 \%$ of the cardiac output is our estimate of the average ana- ent is present at low alveolar oxygen tensions, but is considered negligible across normal alveolar membranes at alveolar oxygen tensions exceeding $100 \mathrm{~mm} \mathrm{Hg}$ (14). Uneven distribution of ventilation in relation to perfusion contributes to shunting whenever alveoli are hypoventilated in relation to their perfusion (14). Atelectasis refers to air spaces that are not ventilated at all and, when perfused, cause shunting.

By the physiologic methods we use in this study it is impossible to distinguish between the venous admixture to arterial blood caused by the anatomical shunt and atelectasis. If, however, we accept $a$ ) that the anatomical component of the total physiologic shunt is, in the patients of this study, almost constant at $2 \%$ of the cardiac output and $b$ ) that diffusing gradients across normal alveolar membranes are negligible at alveolar oxygen tensions of above $100 \mathrm{~mm} \mathrm{Hg}$ (14), we can make two conclusions about the components of the total physiologic shunt: 1) When 100\% oxygen is inspired, the shunt caused by atelectasis is approximately equal to the total physiologic shunt minus $2 \%$ of the cardiac output (this assumes that denitrogenation of the patient has abolished the effect of uneven distribution). 2) The contribution of uneven distribution to the total physiologic shunt can be defined by the relatively simple technique of measuring the shunt, both when $100 \%$ oxygen and when room air is inspired. ${ }^{2}$

tomic shunt present in the patients of this study before surgery.

2 These two conclusions each contain assumptions that require amplification. Our apparent dismissal of the effect of diffusing gradients is a matter of semantics. If, because of uneven distribution of ventilation in relation to perfusion, the oxygen tension of an alveolus is lowered sufficiently, then diffusing gradients may occur across that alveolar membrane. Primarily this is 
Uneven distribution of ventilation in relation to perfusion requires the presence in the hypoventilated alveoli of a "third" gas such as nitrogen in order to cause a significant alveolar-arterial oxygen gradient, or shunt. When $100 \%$ oxygen is inspired for a prolonged period, no such third gas is present; as long as any degree of ventilation of an air space persists, the oxygen tension in this air space can fall only as many millimeters of $\mathrm{Hg}$ as the carbon dioxide tension rises. Consequently, no significant shunt is caused by uneven distribution on $100 \%$ oxygen.

The purpose of this study was to determine the degree of physiologic shunting following open heart surgery, to identify the pulmonary pathophysiology causing this increased shunt, and to ascertain, if possible, whether a specific lesion can be recognized radiologically that may be considered a characteristic consequence of extracorporeal circulation.

\section{Methods}

Eighteen patients (Table I) were selected randomly from among those who underwent elective aortic or mitral valve surgery during a 6 -month period. These 18 patients were divided into three groups: $a$ ) those who underwent aortic valve replacement (in one case debridement) and who at cardiac catheterization had no apparent mitral valve disease, $b$ ) those who underwent mitral valvuloplasty without extracorporeal circulation, and $c$ ) those who had mitral valve replacement or open valvuloplasty with the aid of extracorporeal circulation. (This group includes one patient who also had replacement of the aortic valve and tricuspid valvuloplasty.)

Fifteen of the eighteen patients had transeptal cardiac catheterization 1 to 4 weeks before operation. At catheterization and during studies 20 to 24 hours after surgery simultaneous samples of blood were obtained from the main pulmonary and right radial arteries, with the patient breathing room air. Immediately before or after arterial sampling, cardiac output was determined by analysis of dye dilution curves with a Gilford 103IR densitometer and a single injection of indocyanine green

"uneven distribution." In this paper we so classify it. If, even when $100 \%$ oxygen is inspired, a diffusing gradient is present because of extreme alveolar thickening, then the obliterated air space is functionally in a state of atelectasis. This form of shunting we classify as due to atelectasis. The shunt-like effect of diffusing gradients caused by thickened alveolar membranes should increase as the inspired oxygen tension is lowered. This increase in the effect of diffusing gradients with change from $100 \%$ oxygen to air is indistinguishable from "uneven distribution"; in this study both are arbitrarily called uneven distribution. (amplification and recording were via a Sanborn 350 system). The dye was injected into the superior vena cava and arterial blood withdrawn from a peripheral artery; cardiac output was calculated from the recorded curve by the method of triangulation (15). In the preoperative studies cardiac output was also determined by the Fick principle, oxygen consumption being measured over 3 minutes by the open circuit method with a Beckman oxygen meter (model E 2). (No significant difference was found between Fick and dye techniques.) In the postoperative studies mixed venous blood was withdrawn through a pulmonary arterial catheter (no. 20 polyethylene). A second catheter of the same size was placed in the left atrium.

The techniques of surgery and extracorporeal perfusion followed principles outlined previously (16-19), except that direct coronary perfusion was provided in all patients who had replacement or correction of their aortic valve. Postoperatively, ventilation was not assisted apart from half hourly deep-breathing for 2 to 3 minutes by face mask and rebreathing bag. The temperature of each patient was monitored with a rectal electrode attached to a K-thermia blanket. ${ }^{3}$ For the period of the postoperative studies the rectal temperature was kept at $38^{\circ} \mathrm{C} \pm 0.2^{\circ} \mathrm{C}$.

Blood samples and dye dilution curves were first obtained with the patient inspiring room air. Subsequently $100 \%$ oxygen 4 was given for a minimum of 20 minutes via a tight-fitting face mask and a nonrebreathing system. (The tightness of the face mask was tested by spot checks of expired gas. For significance of possible errors in this method, see Table II.) Blood sampling and dye curves were then repeated. At the conclusion of the studies an X ray of the chest was taken. All blood samples were taken over at least three respiratory cycles. Expired gas and oxygen tanks were analyzed with a Beckman oxygen analyzer (model E 2) or by the Scholander micromethod (20). Patients were supine with a 15 degree head-up tilt.

In the postoperative studies arterial and pulmonary arterial blood was analyzed for oxygen tension, carbon dioxide tension, $\mathrm{pH}$, oxygen content, and oxygen capacity $\left(\mathrm{Po}_{2}=150 \mathrm{~mm} \mathrm{Hg}\right.$, temperature, $\left.38^{\circ} \mathrm{C}\right)$. In the preoperative studies the only blood analyses made were for oxygen content and capacity.

Carbon dioxide tensions $\left(\mathrm{PaCO}_{2}\right.$ and $\left.\mathrm{P}_{\mathrm{v}_{2}}\right)$ were measured with the Severinghaus electrode (21), and $\mathrm{pH}$ was measured with a Radiometer microcapillary glass electrode. Oxygen tensions $\left(\mathrm{Pa}_{\mathrm{O}_{2}}\right.$ and $\left.\mathrm{P} \overline{\mathrm{Y}}_{2}\right)$ were recorded with a modified Clark electrode 5 (0.001-inch platinum cathode) (22) using a Sanborn polarization cell (model 350-416). Great care was taken to perform the polarographic measurements with the blood at $38^{\circ} \mathrm{C}$ within 3

3 Model R.K. 101, Gorman-Rupp Industries, Inc., Bellville, Ohio.

$4100 \%$ oxygen when analyzed contained 0.2 to $0.5 \%$ impurities.

5 Beckman macroelectrode manufactured by Beckman Instruments Co., Fullerton, Calif. 


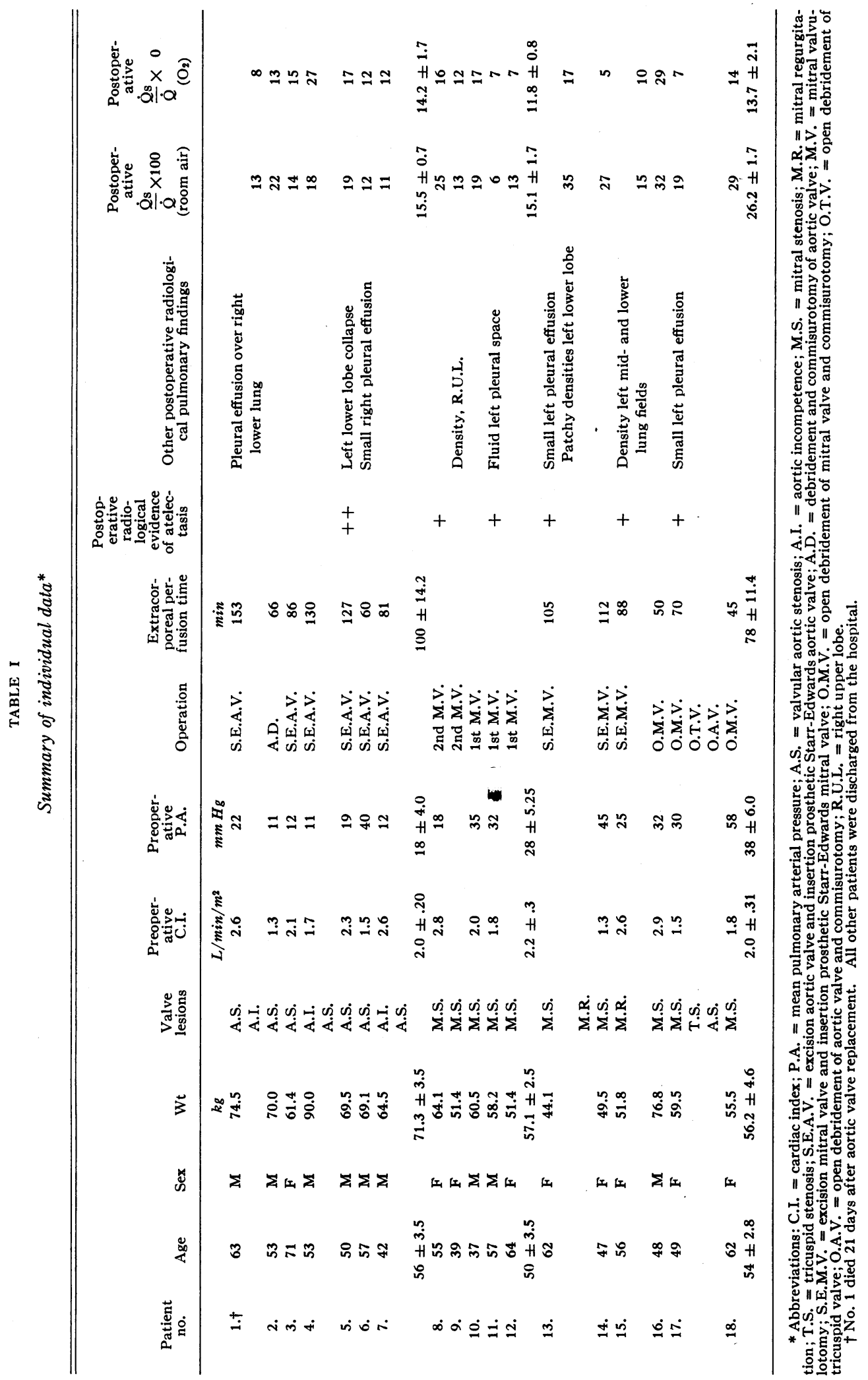


TABLE II

Possible errors in measurements*

\begin{tabular}{|c|c|c|c|}
\hline \multirow[b]{2}{*}{ Source of error } & \multicolumn{2}{|c|}{$\begin{array}{l}\text { Shunt } \\
\text { estimated error } \\
\text { (expressed as per cent of } \\
\text { cardiac output) } \\
\text { when inspiring } \\
\end{array}$} & \multirow[b]{2}{*}{ Reference } \\
\hline & Air & $100 \% \mathrm{O}_{2}$ & \\
\hline \multirow{4}{*}{$\begin{array}{l}\text { Laboratory error in } \mathrm{O}_{2} \text { content } \\
\text { determination } \dagger \\
\text { Laboratory error in } \mathrm{P}_{\mathrm{O}_{2}} \text { or } \mathrm{P}_{\mathrm{CO}_{2}} \\
\text { determination } \ddagger \\
\text { A-aD for } \mathrm{P}_{\mathrm{CO} 2} \text { caused by shunt } \\
\text { Variation in expired and metabolic } \mathrm{R} \\
\quad \text { from } 0.85\end{array}$} & $\pm 5 \%$ & $\pm 5 \%$ & 23 \\
\hline & & & \\
\hline & $\begin{array}{r}<0.5 \% \\
-2 \%\end{array}$ & $\begin{array}{l}<0.5 \% \\
<0.5 \%\end{array}$ & $\begin{array}{l}21,22,25 \\
26\end{array}$ \\
\hline & $\pm 5 \%$ & $<0.5 \%$ & 27 \\
\hline $\begin{array}{l}\text { Inaccuracy of } 0.0031 \text { as Bunsen solu- } \\
\text { bility coefficient for } \mathrm{O}_{2} \text { in W.B. } \\
\text { Venous admixture from other than }\end{array}$ & $<0.5 \%$ & $\pm 2 \%$ & 24,25 \\
\hline $\begin{array}{l}\text { Venous admixture from other than } \\
\text { right heart } \\
\text { Inert gas in alveoli }\end{array}$ & $\pm 0.8 \%$ & $\begin{array}{l} \pm 0.8 \% \\
<\quad 3 \%\end{array}$ & $\begin{array}{l}12 \\
\text { (There would be approximately a } 3 \% \text { error in } \\
\text { calculation of shunt if } 6 \% \text { inert gas was } \\
\text { present in the expired gas after } 20 \text { minutes } \\
\text { of oxygen breathing.) }\end{array}$ \\
\hline $\begin{array}{l}\text { Inaccuracy or inapplicability of hemo- } \\
\text { globin dissociation curve of Dill }\end{array}$ & $-2 \%$ & & $28,29,30$ \\
\hline $\begin{array}{l}\text { The assumption of equal } \mathrm{pH} \text { for arterial } \\
\text { and alveolar equilibrated blood }\end{array}$ & $-0.5 \%$ & & 30 \\
\hline
\end{tabular}

The measurement of physiologic shunt expressed as per cent of the cardiac output $Q(Q s / Q \times 100)$ thus carries a random error of $\pm 5 \%$ of the cardiac output.

\begin{tabular}{|c|c|c|}
\hline Source of error & $\begin{array}{l}\text { Alveolar ventilation } \\
\text { estimated error } \\
\text { in } \% \text { of } \dot{\mathrm{V}}_{\mathbf{A}}\end{array}$ & Reference \\
\hline $\begin{array}{l}\mathrm{A}-\mathrm{aD} \text { for } \mathrm{P}_{\mathrm{CO}_{2}} \text { caused by shunt } \\
\text { Calculation of } \dot{\mathrm{V}}_{\mathrm{O}_{2}} \\
\text { Assumption of } \mathrm{R}_{\text {of }} 0.85\end{array}$ & $\begin{array}{l}<4-5 \% \\
< \pm 20 \% \\
< \pm 30 \%\end{array}$ & $\begin{array}{l}26,31 \\
15 \\
\text { If } \mathrm{R} \text { was } 1.1 \text { the error in calculation of } \dot{\mathrm{V}}_{\mathrm{A}} \\
\text { is }[(1.1-0.85) / 0.85 \times 100] \%=29 \% .\end{array}$ \\
\hline
\end{tabular}

The measurements of $\dot{\mathrm{V}}_{\mathrm{A}}$ and $\dot{\mathrm{V}}_{\mathrm{O}_{2}}$ shown in Table III thus carry a random error of approximately $\pm 30 \%$.

* Abbreviations: $\mathrm{P}_{\mathrm{O}_{2}}=$ oxygen tension; $\mathrm{P}_{\mathrm{CO}_{2}}=$ carbon dioxide tension; $\mathrm{A}-\mathrm{aD}=$ alveolar-arterial $\mathrm{O}_{2}$ difference; $\mathrm{R}=$ respiratory quotient; W.B. = whole blood; $\dot{\mathrm{V}}_{\mathrm{O}_{2}}=$ oxygen consumption.

$\dagger$ Mean error of duplicate analyses: 0.12 vol per $100 \mathrm{ml}, \mathrm{SD} \pm 0.17$.

Mean error of duplicate analyses: $1.8 \%, \mathrm{SD} \pm 1.2 \%$. Mean error of individual measurement with tonometered blood or water: $1.9 \%, \mathrm{SD} \pm 1.6 \%$.

minutes from sampling. The accuracy of Severinghaus and Clark electrodes was repeatedly checked against water or blood equilibrated with known percentages of oxygen and carbon dioxide. For $\mathrm{Po}_{2}$ and $\mathrm{P}_{\mathrm{CO}_{2}}$ the reproducibility of any particular sample was found to be within $2 \%$. The oxygen contents of the pulmonary artery $\left(\mathrm{C} \overline{\mathrm{V}}_{2}\right)$ and arterial blood $\left(\mathrm{Ca}_{2}\right)$ were determined by the method of Van Slyke and Neill (23). All measurements were required to check to within \pm 0.2 vol per $100 \mathrm{ml}$ for any particular sample. Oxygen capacity at $\mathrm{P}_{\mathrm{O}_{2}}=150 \mathrm{~mm} \mathrm{Hg}$, temperature, $38^{\circ} \mathrm{C}$ (Cap), was determined by equilibrating the blood at $38^{\circ} \mathrm{C}$ with a known oxygen tension in excess of $140 \mathrm{~mm} \mathrm{Hg}$ and then measuring the blood oxygen content. Correction for discrepancy in dissolved oxygen was made by subtracting or adding the multiple of 0.0031 times the amount the tension differed from 150 [0.0031 is the Bunsen coefficient for the amount of oxygen physically dissolved in blood (volume per $100 \mathrm{ml}$ ) under a pressure gradient of $1 \mathrm{~mm} \mathrm{Hg}$ at $\left.38^{\circ} \mathrm{C}\right](24,25)$. After tonometry the oxygen tension of the blood always agreed to within $2 \%$ of the oxygen tension of the equilibrating gas. The technique of tonometry used to determine the oxygen capacity has been previously described by Hedley-Whyte and Laver (25).

The $\mathrm{X}$ rays of the chest taken at the conclusion of the studies were examined independently by two radiologists.

The statistical methods and the equations used to calculate ideal alveolar oxygen tension $\left(\mathrm{PaO}_{2}\right)$, total physiologic shunt $(\dot{Q} s / \dot{Q} \times 100)$, oxygen consumption $\left(\hat{V o}_{2}\right)$, and alveolar ventilation ( $\left.\nabla_{A}\right)$ are shown in the Appendix.

Table II shows the source of possible errors in this study and gives our own and previous workers' (12, 15, 21-31) estimates of the significance of these errors.

We submit that the majority of the errors cited in Table II operate randomly, and we therefore believe that 
TABLE III

Effect of $100 \% \mathrm{O}_{2}$ and room air 20 to 24 hours after surgery (mean values $\pm S E$ )*

\begin{tabular}{|c|c|c|c|c|c|c|c|c|c|c|}
\hline & PaOz & Pao2 & $\mathrm{PaCO}_{2}$ & $\mathrm{pH}$ & $\mathrm{CaO}_{2}$ & $\mathrm{C}_{\overline{\mathrm{v}}} \mathrm{o}_{2}$ & C.I. & $\dot{V}_{02}$ & $\dot{\mathbf{V}}_{\mathbf{A}}$ & L.A. mean \\
\hline Open aortic & $\begin{array}{c}m m H g \\
101 \pm 2.1 \\
669 \pm 4.8\end{array}$ & $\begin{array}{c}m m H g \\
65 \pm 3.9 \\
319 \pm 43.9\end{array}$ & $\begin{array}{c}m m \mathrm{Hg} \\
42 \pm 1.2 \\
42 \pm 3.2\end{array}$ & $\begin{array}{l}7.39 \pm 0.04 \\
7.40 \pm 0.02\end{array}$ & $\begin{array}{c}m l / 100 \\
m l W . B . \\
17.2 \pm 0.8 \\
19.2 \pm 0.8\end{array}$ & $\begin{array}{c}m l / 100 \\
m l W . B . \\
11.4 \pm 0.6 \\
12.0 \pm 0.7\end{array}$ & $\begin{array}{l}L / \min / \mathrm{m}^{2} \\
2.8 \pm 0.4 \\
2.7 \pm 0.5\end{array}$ & $\begin{array}{c}\mathrm{ml} / \mathrm{min} / \mathrm{m}^{2} \\
156 \pm 18 \\
177 \pm 22\end{array}$ & $\begin{array}{l}L / \mathrm{min} / \mathrm{m}^{2} \\
2.7 \pm 0.3 \\
3.6 \pm 0.6\end{array}$ & $\begin{array}{c}m m \mathrm{Hg} \\
9.9 \pm 1.5 \\
10.6 \pm 1.9\end{array}$ \\
\hline Closed mitral & $\begin{array}{l}104 \pm 2.5 \\
671 \pm 65.0\end{array}$ & $\begin{array}{r}67 \pm 3.6 \\
356 \pm 65.0\end{array}$ & $\begin{array}{l}39 \pm 2.4 \\
41 \pm 3.1\end{array}$ & 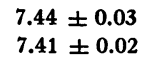 & $\begin{array}{l}15.9 \pm 1.0 \\
18.0 \pm 1.0\end{array}$ & $\begin{array}{l}9.7 \pm 0.9 \\
9.7 \pm 1.1\end{array}$ & $\begin{array}{l}2.0 \pm 0.3 \\
2.2 \pm 0.4\end{array}$ & $\begin{array}{l}130 \pm 36 \\
169 \pm 63\end{array}$ & $\begin{array}{l}2.5 \pm 0.8 \\
3.6 \pm 1.4\end{array}$ & $\begin{array}{l}9.6 \pm 0.3 \\
8.8 \pm 0.6\end{array}$ \\
\hline Open mitral & $\begin{array}{l}104 \pm 2.4 \\
669 \pm 2.6\end{array}$ & $\begin{array}{r}53 \pm 3.1 \\
324 \pm 54.4\end{array}$ & $\begin{array}{l}40 \pm 2.3 \\
44 \pm 2.0\end{array}$ & 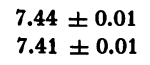 & $\begin{array}{l}16.4 \pm 1.3 \\
19.8 \pm 1.3\end{array}$ & $\begin{array}{r}9.2 \pm 0.6 \\
11.5 \pm 0.7\end{array}$ & $\begin{array}{l}2.0 \pm 0.2 \\
2.0 \pm 0.4\end{array}$ & $\begin{array}{l}151 \pm 12 \\
145 \pm 25\end{array}$ & $\begin{array}{l}2.8 \pm 0.3 \\
2.8 \pm 0.5\end{array}$ & $\begin{array}{r}9.0 \pm 2.2 \\
10.5 \pm 2.3\end{array}$ \\
\hline
\end{tabular}

* Abbreviations: $\mathrm{PAO}_{2}=$ alveolar oxygen tension; $\mathrm{PaO}_{2}=$ arterial oxygen tension; $\mathrm{PacO}_{2}=$ carbon dioxide arterial tension; $\mathrm{CaO} 2=$ oxygen content of arterial blood; $\mathrm{C}_{\overline{\mathrm{V}} \mathrm{O}_{2}}=$ oxygen content of the pulmonary artery; C.I. = cardiac index; $\dot{\mathrm{V}}_{2}=$ oxygen consumption; $\dot{\mathrm{V}}_{\mathrm{A}}=\mathrm{alveolar}$ ventilation; L.A. = left atrial pressure.

any individual measurement of shunt had a random error of less than $\pm 5 \%$ of the cardiac output. This degree of accuracy is sufficient for the purposes of this study but would not be sufficient for the study of physiologic shunting in normal man.

Our technique for measuring alveolar ventilation ( $V_{A}$ ) and oxygen consumption $\left(\mathrm{VO}_{2}\right)$ is subject to random errors of $\pm 30 \%$. These parameters are included in $\mathrm{Ta}$ ble III only to show that increased physiologic shunting was not caused by alveolar hypoventilation or by changes in $\mathrm{Vo}_{2}$.

\section{Results}

Decreased oxygenation and large physiologic shunts were found in all patients, when studied 20 to 24 hours after cardiac surgery. The degree of impaired oxygenation was such that arterial oxygen tensions were in the hypoxic range. When the patients were allowed to breathe room air after closed mitral valvulotomy, mean $\mathrm{Pa}_{\mathrm{O}_{2}}$ was 67

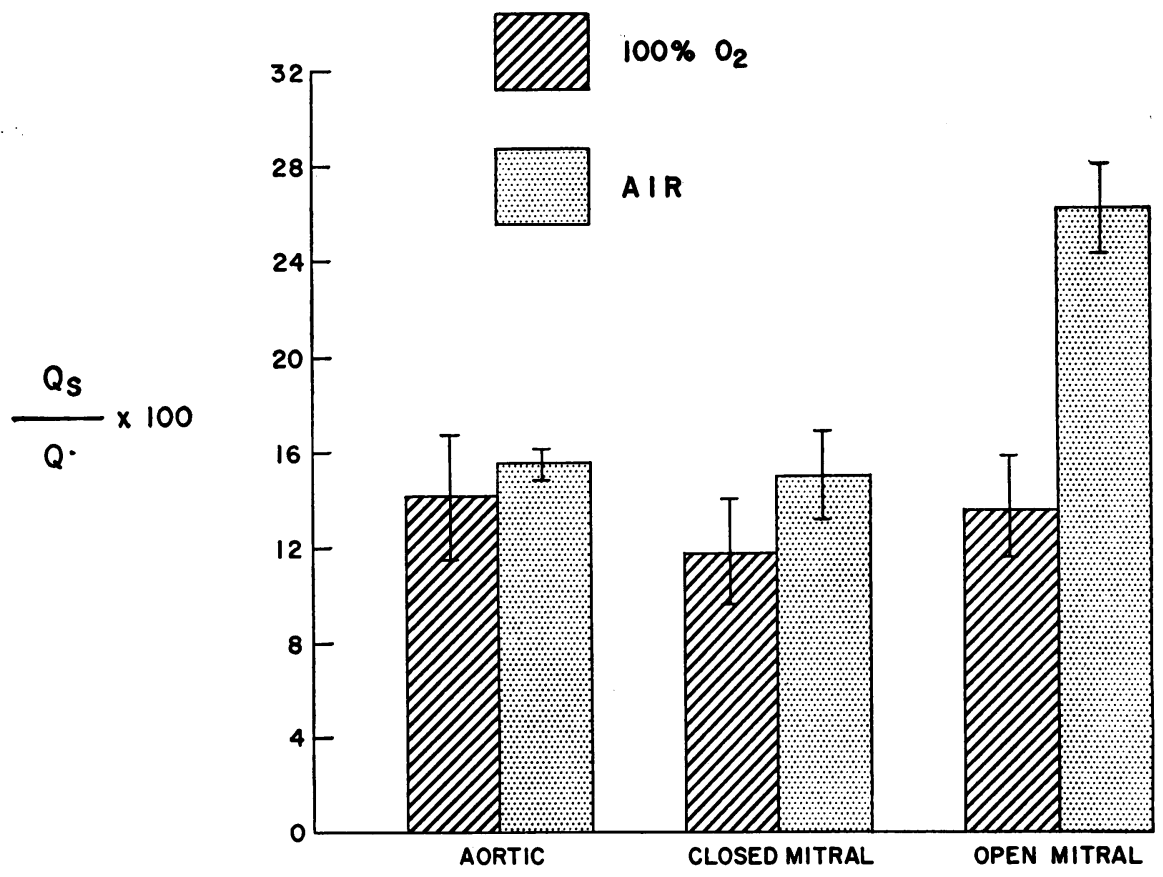

Fig. 1. Mean values ( $\pm \mathrm{SE}$ ) for physiologic shunt (PUlmonary venous adMIXTURE) 20 TO 24 HOURS AFTER AORTIC VALVE REPLACEMENT, CLOSED MITRAL VALVULOTOMY, OR OPEN MITRAL VALVE REPLACEMENT OR REPAIR. Values for shunt breathing $100 \% \mathrm{O}_{2}$ are compared with the shunt breathing air. The shunt breathing air is significantly greater $\left(\mathrm{p}<0.01\right.$ ) than the shunt breathing $100 \% \mathrm{O}_{2}$ in the patients who have had open mitral valve replacement or repair. 


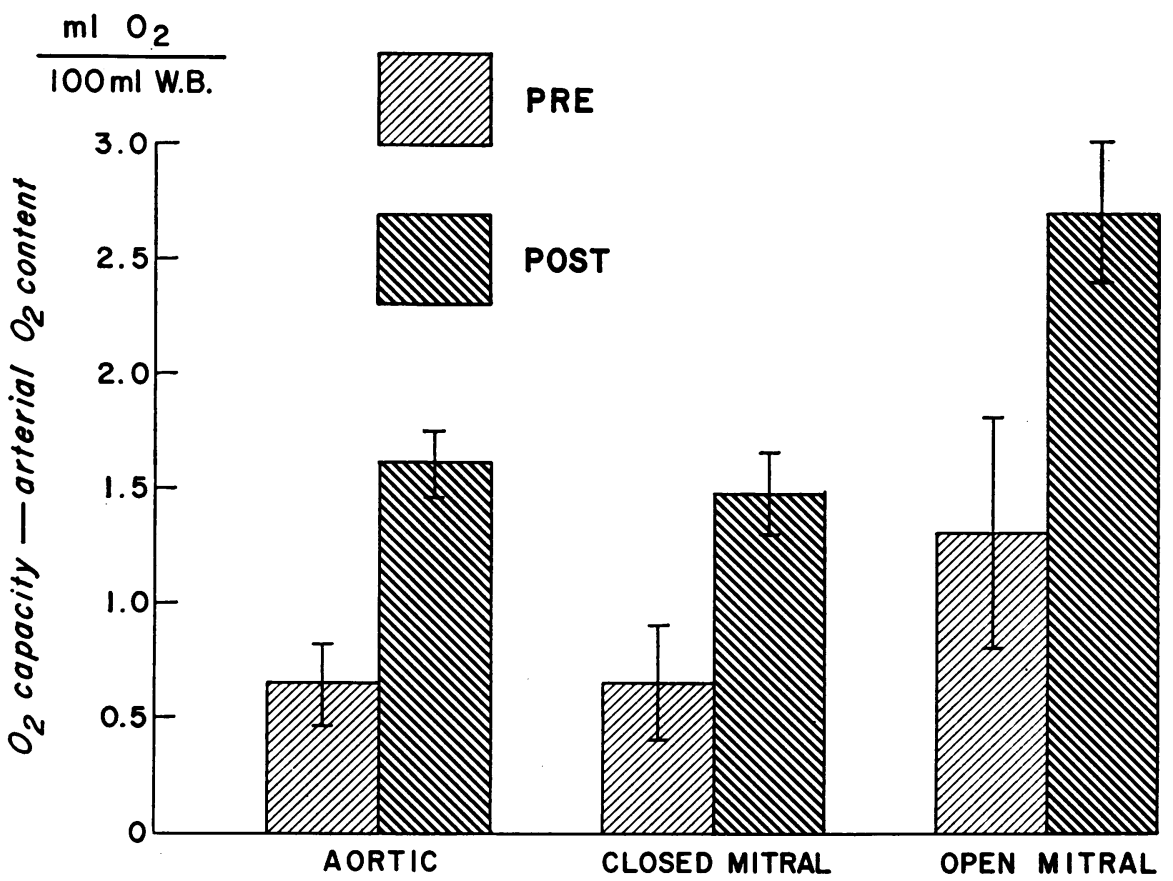

Fig. 2. Mean values ( $\pm \mathrm{SE}$ ) for $\mathrm{O}_{2}$ capacity minus arterial $\mathrm{O}_{2}$ content ( $\mathrm{ml} \mathrm{O}_{2}$ PER 100 ML WHOLE BLOOD) WHEN BREATHING AIR. Preoperative values were obtained at cardiac catheterization 1 to 4 weeks before aortic valve replacement, closed mitral valvulotomy, or open mitral valve replacement or repair. Postoperative values were obtained 20 to 24 hours after surgery and are significantly greater than the differences between $\mathrm{O}_{2}$ capacity and arterial $\mathrm{O}_{2}$ content found before operation $(\mathrm{p}<0.01$ for the aortic, $\mathrm{p}<0.1$ for the closed mitral, and $\mathrm{p}<0.05$ for the open mitral patients).

$\mathrm{mm} \mathrm{Hg}$; after open aortic valve replacement mean $\mathrm{Pa}_{\mathrm{O}_{2}}$ was $65 \mathrm{~mm} \mathrm{Hg}$, and after open mitral surgery mean $\mathrm{Pa}_{\mathrm{O}_{2}}$ was only $53 \mathrm{~mm} \mathrm{Hg}$ (Table III).

The postoperative shunts were measured both on $100 \%$ oxygen and on room air. On $100 \%$ oxygen the average shunts were 12,14 , and $14 \%$ of cardiac output after closed mitral, open aortic, and open mitral valve surgery, respectively. On room air the corresponding values were 15,15 , and $26 \%$ of cardiac output (Figure 1 and Table I). Thus the shunt was invariably larger on room air, but only after open mitral surgery did the difference reach proportions that are statistically significant $(p<0.01)$. The postoperative shunts on $100 \%$ oxygen and on room air are shown graphically in Figure 1. The contribution of uneven distribution to shunting can be obtained from the values shown in Figure 1 by subtracting the shunt on $100 \%$ oxygen from the shunt on room air.

Impairment of oxygenation was markedly increased by surgery (Figure 2 ). For comparison of postoperative with preoperative values the impaired oxygenation is expressed as oxygen capacity (in vol per $100 \mathrm{ml}$ at $\mathrm{Po}_{2}$ of $150 \mathrm{~mm} \mathrm{Hg}$ ) minus arterial oxygen content. It is apparent that this difference between oxygen capacity and arterial oxygen content was more than doubled in all three groups; increases were significant at a level of $\mathrm{p}<0.01$ after aortic surgery, $\mathrm{p}<0.05$ after closed mitral surgery, and $p<0.1,>.05$ after open mitral surgery. The patients having open mitral surgery had the largest preoperative impairment of oxygenation. This postoperative increase in the difference between oxygen capacity and arterial oxygen content was not caused by an increased oxygen carrying capacity of the blood since the over-all average oxygen capacity was 19.3 vol per $100 \mathrm{ml}$ before operation and $19.0 \mathrm{vol}$ per $100 \mathrm{ml} 24$ hours after surgery.

In an attempt to determine a possible causal relationship, the postoperative increase in the difference between oxygen capacity and arterial oxy- 
gen content was tested for correlation with the following variables, none of which was significant at the 5\% level: hypoventilation (Table III), changes in cardiac output (Tables I and III), radiological evidence of atelectasis (Table I), anemia (Table III), pulmonary arterial hypertension (Figure 3 ), or left atrial hypertension (Table III). Oxygen consumption increased an average of $20 \%$ after operation, consistent with an observed average increase in oral temperature of $1.2^{\circ} \mathrm{C}$. Figure 4 shows the abnormally large arteriovenous $\mathrm{O}_{2}$ differences found in many of the patients.

Hypoventilation was not present at the time of the postoperative study, as shown by $\mathrm{Pa}_{\mathrm{CO}_{2}}$ values in Table III. The highest postoperative $\mathrm{Pa}_{\mathrm{CO}_{2}}$ value was $52 \mathrm{~mm} \mathrm{Hg}$, obtained in a 71year-old patient breathing room air after open aortic surgery. Acid-base balance was almost normal, with little evidence of either respiratory or metabolic acidosis. The lowest $\mathrm{pH}$ at the time of study was 7.32 , and this modest acidosis was metabolic rather than respiratory in nature. Detailed tables of the following parameters: $\mathrm{Pa}_{\mathrm{O}_{2}}$, $\mathrm{Pa}_{\mathrm{CO}_{2}}, \mathrm{pH}, \mathrm{Ca}_{\mathrm{O}_{2}}, \mathrm{C}_{\mathrm{O}_{2}}$, cardiac index (C.I.), mean pulmonary arterial pressure (P.A.), left atrial pressure (L.A.), and oxygen consumption

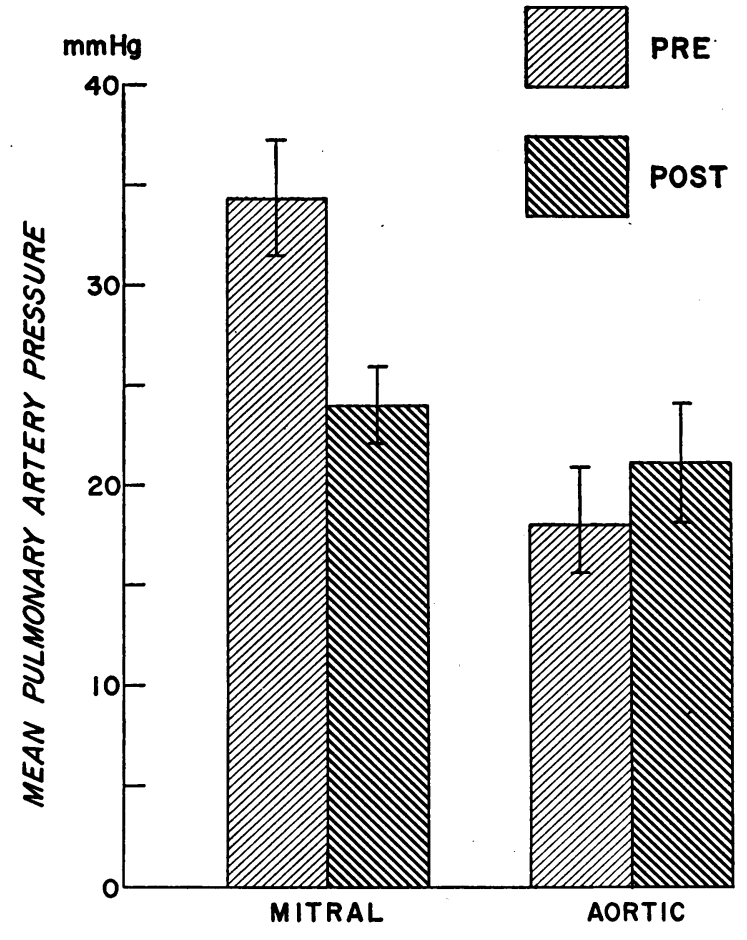

Fig. 3. Mean values ( $\pm \mathrm{SE}$ ) for pulmonary arTERIAL PRESSURE 1 TO 4 WEEKS BEFORE AND 20 TO 24 HOURS AFTER PROSTHETIC REPLACEMENT OF THE AORTIC OR MITRAL valve. The decrease in pulmonary arterial pressure was significant $(\mathrm{p}<0.01)$ after mitral valve replacement or repair.

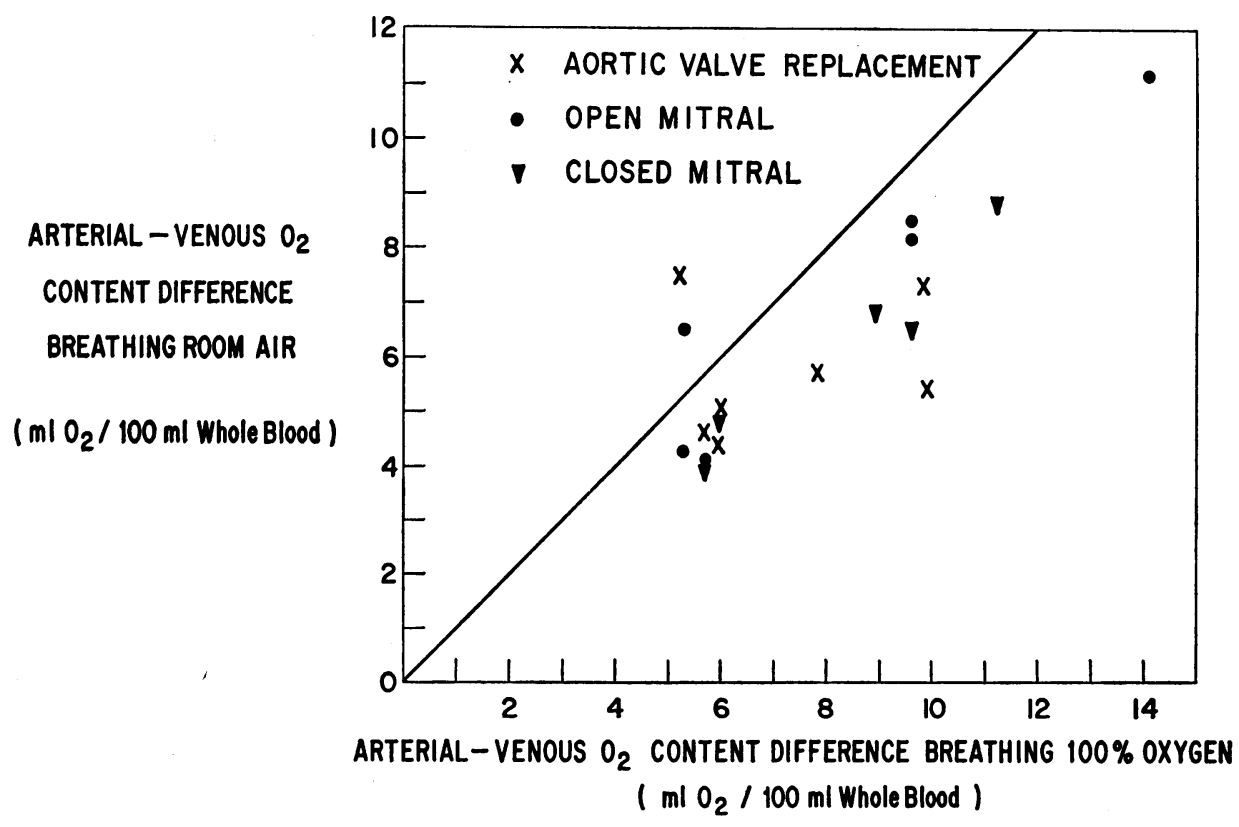

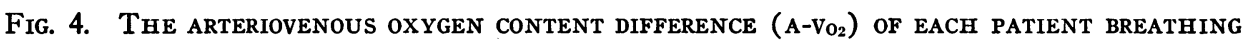
AIR PLOTted Against the A-V $\mathrm{V}_{2}$ DIFFERENCE WHEN BREATHING $100 \%$ OXYGEN. 
$\left(\mathrm{V}_{\mathrm{O}_{2}}\right)$ have been deposited ${ }^{6}$ and are available on request.

One patient in this study died (Patient 1, Table I). Death occurred 21 days after these studies, and autopsy confirmed the clinical diagnosis of acute tubular necrosis.

\section{Discussion}

After cardiac surgery arterial oxygen tension fell to hypoxic levels when room air was inspired. The cause of this increased hypoxemia was physiologic shunting. These large shunts were also present while the patients were breathing $100 \%$ oxygen, and thus we conclude that the most important single cause of postoperative shunting in these patients was atelectasis. This lesion is defined in pathophysiological terms as a state of continued perfusion of alveoli that receive no ventilation at all.

These perfused but unventilated alveoli were probably widely scattered, and essentially no agreement was found between atelectasis as here defined and conventional radiological evidence of atelectasis (Table I).

There was no significant difference in the magnitude of shunts in the three groups studied, regardless of whether extracorporeal circulation was used or not. This finding is compatible with other reports that indicate that hypoxemia is generally present after all major surgery (1-6). Only McClenahan, Sykes, and Young (9) have suggested that hypoxemia and large shunts are a unique consequence of open heart surgery.

The increase in shunting on room air, as compared with $100 \%$ oxygen, was modest except in the patient group that had open mitral surgery. This increase in shunting may be explained on the basis of uneven distribution of ventilation in relation to perfusion; as the "third" gas, nitrogen, becomes available, an additional shunt effect is caused by alveoli that are hypoventilated in relation to their perfusion. If the distribution of ven-

\footnotetext{
${ }^{6}$ Detailed tables of these nine parameters have been deposited as document number $\mathbf{8 2 3 5}$ with the American Documentation Institute Auxiliary Publications Project, Photoduplication Service, Library of Congress, Washington, D. C. 20540 . A copy may be secured by citing the document number and remitting $\$ 1.25$ for photoprints or 35 mm microfilm. Advance payment is required. Make checks or money orders payable to: Chief, Photoduplication Service, Library of Congress.
}

tilation is sufficiently uneven, one must assume that a diffusing gradient adds to the shunt, because in the least ventilated alveoli the oxygen tension may be sufficiently low, or the alveolar membranes sufficiently thickened, to establish a diffusing block.

The addition of the distribution effect is not the only possible cause of increased shunting on room air. The shunt equation (see Appendix) makes it evident that, with the numerator (i.e., the A-a $\mathrm{O}_{2}$ gradient) constant, any decrease in the denominator (i.e., the $\mathrm{A}-\overline{\mathrm{v}} \mathrm{O}_{2}$ gradient) will result in a higher numerical value of the shunt. Figure 4 demonstrates that the $\mathrm{A}-\overline{\mathrm{v}} \mathrm{O}_{2}$ gradients were consistently lower (approximately 20 to 25\%), as expected, on room air than on $100 \%$ oxygen. Therefore, the larger shunts on room air are explainable, in part, on the basis of a fall in $A-\bar{v} \mathrm{O}_{2}$ gradients. A redistribution of pulmonary blood flow is a further possibility: in order to explain an increase in shunt on this basis one would have to assume a redistribution favoring the "shunt-producing" gas exchange units. Although not likely to account for the entire change, this can neither be proved nor disproved.

Patients with mitral stenosis are known to have parenchymal lung changes that may cause significant uneven distribution of ventilation in relation to perfusion (32). In our present study, however, only in the group who had mitral valve replacement or open repair was the shunt so much larger on room air than on $100 \%$ oxygen that the uneven distribution effect became a major component of the shunt. In this group the shunt doubled on room air, and so large an increase is clearly not explicable on the basis of change in the $\mathrm{A}-\overline{\mathrm{v}} \mathrm{O}_{2}$ gradient. The degree of shunting, moreover, bore no relation to the degrees of postoperative pulmonary hypertension.

By the techniques used in this study we cannot prove or disprove a marked postoperative increase in that portion of the bronchial arterial flow that drains into the left atrium. However, the magnitude of the postoperative impairment of oxygenation found in every patient makes it unlikely that these channels (12) are a major source of postoperative shunting. Likewise it seems difficult to conceive that other sources of the normal anatomical shunt, such as the Thebesian vessels, can contribute significantly to the observed large increases in the total physiologic shunt. 
We suggest therefore that atelectasis with significant shunting is the common denominator in causing postoperative impairment of oxygenation. Similar studies done during operation (unpublished data) have revealed that shunting of similar magnitude is present at this time and that the shunt before the period of extracorporeal circulation is just as large as the shunt after perfusion, the pattern of ventilation being identical. The oxygenation impairment cannot, therefore, be related to any specific pulmonary damage inflicted during the period of perfusion. Instead, the atelectasis and shunting found postoperatively in these studies must be explained as insufficient re-expansion of the lungs during and after the period of open chest surgery and also on the basis of an unfavorable pattern of ventilation.

In previous studies (33-36) we have found the pattern of ventilation to be the single most important factor in determining the degree of atelectasis and shunting; a pattern of fast and shallow breathing promotes atelectasis and shunting, whereas large tidal volumes prevent this complication (34). Periodic deep breathing with very large tidal volumes is effective in reversing atelectasis and shunting of relatively short duration $(33,36)$. The most important causes of shallow breathing, lacking in spontaneous, periodic deep breaths, are pain and morphine given for relief of pain (37).

Thus, we have found the major pulmonary complication of cardiac surgery to be deficient oxygenation rather than hypoventilation. Accordingly, we do not use mechanical respiratory support routinely, only on specific indications. Instead, the postoperative regimen calls for careful monitoring of arterial and venous blood gases, for the use of sufficient inspired oxygen to produce an arterial oxygen tension of $100 \mathrm{~mm} \mathrm{Hg}$, for intensive chest physiotherapy with coughing and deep breathing exercises, and for passive deep breathing every 30 minutes around the clock.

\section{Summary}

Large physiologic shunts causing hypoxemia were found in all patients on air 20 to 24 hours after cardiac surgery. The average physiologic shunt on $100 \%$ oxygen was $13 \%$ of cardiac output, and it was concluded that the most important single cause of these shunts was diffuse atelectasis, usu- ally invisible to $\mathrm{X}$ ray. Extracorporeal circulation had no apparent effect in increasing physiologic shunting. However, the increase in shunting on room air, as compared with oxygen, was significant in the group of patients who had mitral valve replacement or open mitral valvuloplasty $(p<0.01)$. This increase, caused by uneven distribution of ventilation in relation to perfusion, was equivalent to a right to left shunt of $12.5 \%$ of the cardiac output. The combination of atelectasis and maldistribution resulted in the mean arterial oxygen tension on air of this group being only $53 \mathrm{~mm} \mathrm{Hg}$.

\section{Appendix}

Calculations. Mean alveolar oxygen tension, $\mathrm{PAO}_{2}$, was calculated from the alveolar gas equation (26) by arbitrarily assuming an $R Q$ of 0.85 when air was inspired.

To derive the per cent of the cardiac output that did not become fully oxygenated on its passage through the pulmonary circulation (total shunt, $\dot{Q} s / \dot{Q} \times 100$ ) the following equation was used (38):

$$
\frac{\dot{\mathrm{Q}} \mathrm{s}}{\dot{\mathrm{Q}}}=\frac{\mathrm{Cc}^{\prime} \mathrm{O}_{2}-\mathrm{Ca}_{\mathrm{O}_{2}}}{\mathrm{C}^{\prime} \mathrm{O}_{2}-\mathrm{C}_{\mathrm{v}_{2}}}
$$

where $\mathrm{Ca}_{\mathrm{O}_{2}}=$ oxygen content of arterial blood, $\mathrm{C}_{\mathrm{O}_{2}}=$ oxygen content of mixed venous blood, and $\mathrm{Cc}^{\prime} \mathrm{O}_{2}=$ the oxygen content that the patient's arterial blood would have had if equilibrated with mean alveolar gas.

Two equations were used to calculate $\mathrm{Cc}^{\prime} \mathrm{o}_{2}$ when $100 \%$ oxygen was inspired:

a) When $\mathrm{PaO}_{2}$ was greater than $150 \mathrm{~mm} \mathrm{Hg}$, advantage was taken of the fact that at these high oxygen tensions hemoglobin is effectively fully saturated. Thus, the difference between $\mathrm{CaO}_{2}$ and $\mathrm{Cc}^{\prime} \mathrm{O}_{2}$ was determined by multiplying the corresponding oxygen tension difference by the Bunsen solubility coefficient for oxygen in blood $(0.0031$ vol per $100 \mathrm{ml}$ per $\mathrm{mm} \mathrm{Hg})(24,25)$.

$$
\mathrm{Cc}^{\prime} \mathrm{O}_{2}=\mathrm{CaO}_{2}+\left(\mathrm{PAO}_{2}-\mathrm{PaO}_{2}\right) \times 0.0031 \text {. }
$$

b) When $\mathrm{PaO}_{2}$ was less than $150 \mathrm{~mm} \mathrm{Hg}$, the oxygen capacity of the blood at $\mathrm{P}_{\mathrm{O}_{2}}=150 \mathrm{~mm} \mathrm{Hg}$, temperature, $38^{\circ} \mathrm{C}$ (Cap), was determined in a tonometer (25). Above $\mathrm{P}_{\mathrm{O}_{2}} 150 \mathrm{~mm} \mathrm{Hg}$ hemoglobin is effectively fully saturated, and thus the difference between $\mathrm{Cc}^{\prime} \mathrm{O}_{2}$ and Cap can be expressed, as in Equation 2, by multiplying the tension difference by the Bunsen solubility coefficient for oxygen in whole blood.

$$
\mathrm{Cc}^{\prime} \mathrm{O}_{2}=\mathrm{Cap}+\left(\mathrm{PA}_{2}-150\right) \times 0.0031 .
$$

The calculation of $\mathrm{Cc}^{\prime} \mathrm{O}_{2}$ when room air was inspired was done in two stages. First, the tables of Dill (30) were read to find the saturation that blood would have if equilibrated with mean alveolar air $\left(\mathrm{Sc}^{\prime} \mathrm{O}_{2}\right)$ (the $\mathrm{pH}$ of this blood was assumed to be the patient's arterial $\mathrm{pH}$ ). Second, the standard formula, 
percentage saturation $=\frac{\left(\mathrm{O}_{2} \text { content-dissolved } \mathrm{O}_{2}\right)}{\mathrm{O}_{2} \text { capacity-dissolved } \mathrm{O}_{2}} \times 100$, was solved for $\mathrm{O}_{2}$ content:

$$
\begin{aligned}
\mathrm{Cc}^{\prime} \mathrm{O}_{2}=\mathrm{Sc}^{\prime} \mathrm{O}_{2} \times(\mathrm{Cap}-0.0031 & \times 150) \\
& +\left(\mathrm{PA}_{\mathrm{O}_{2}} \times 0.0031\right) .
\end{aligned}
$$

Oxygen consumption, milliliters $\mathrm{O}_{2}$ per square meter per minute $\left(\dot{\mathrm{V}}_{\mathrm{O}_{2}}\right)$, was calculated from the cardiac index and the arteriovenous oxygen content difference $\left(\mathrm{a}-\mathrm{v} \mathrm{O}_{2}\right)(31)$.

$$
\dot{\mathrm{V}}_{\mathrm{O}_{2}}=10 \text { C.I. } \times \text { a-v O},
$$

where C.I. is the cardiac index in liters per square meter per minute.

Alveolar ventilation $(\dot{\mathrm{V}} \mathrm{A})$, liters per minute, was calculated from the following equation (31):

$$
\dot{\mathrm{V}}_{\mathrm{A}}=\frac{0.863 \cdot \dot{\mathrm{V}}_{\mathrm{O}_{2}} \cdot \mathrm{R}}{\mathrm{PaCO}_{2}}
$$

where $\mathrm{R}$ is the respiratory quotient (arbitrarily assumed to be 0.85 ).

Statistical testing of the effect of operation and of breathing $100 \%$ oxygen was by the $t$ test, using the method of paired comparison (39).

\section{Acknowledgments}

We thank Dr. J. Gordon Scannell for valuable help and the permission to study his patients. Dr. C. Sanders was responsible for the preoperative diagnostic cardiac catheterization; throughout this study he gave us much encouragement and advice. We also thank Dr. E. P. Radford, Jr., Associate Professor of Physiology, Harvard School of Public Health, for his critical review of this manuscript. The expert technical assistance of Miss A. Murphy, Dr. A. Seifen, Miss A. Quinn, Miss B. Mallinckrodt, and Miss C. Pistorino is gratefully acknowledged.

\section{References}

1. Maier, H. C., and A. Cournand. Studies of arterial oxygen saturation in the postoperative period after pulmonary resection. Surgery 1943, 13, 199.

2. Björk, V. O., and H. J. Hilty. The arterial oxygen and carbon dioxide tension during postoperative period in cases of pulmonary resections and thoracoplasties. J. thorac. Surg. 1954, 27, 455.

3. Hood, R. M., and A. C. Beall, Jr. Hypoventilation, hypoxia, and acidosis occurring in the acute postoperative period. J. thorac. Surg. 1958, 36, 729.

4. Gordh, T., H. Linderholm, and O. Norlander. Pulmonary function in relation to anesthesia and surgery evaluated by analysis of oxygen tension of arterial blood. Acta anaesth. scand. 1958, 2, 15.

5. Clowes, G. H. A., Jr., G. A. Sabga, A. Konitaxis, R. Tomin, M. Hughes, and F. A. Simeone. Effects of acidosis on cardiovascular function in surgical patients. Ann. Surg. 1961, 154, 524.

6. DiBenedetto, A., P. Glass, A. A. Siebens, and R. Klopstock. The effects of limited pulmonary re- section on ventilation-perfusion relationships in the postoperative period. J. thorac. cardiovasc. Surg. 1963, 45, 312.

7. Osborn, J. J., R. W. Popper, W. J. Kerth, and F. Gerbode. Respiratory insufficiency following open heart surgery. Ann. Surg. 1962, 156, 638.

8. Damman, J. F., Jr., N. Thung, I. I. Christlieb, J. B. Littlefield, and W. H. Muller, Jr. The management of the severely ill patient after open heart surgery. J. thorac. cardiovasc. Surg. 1963, 45, 80.

9. McClenahan, J. B., M. K. Sykes, and W. Young. Changes in pulmonary physiology following extracorporeal circulation (abstract). Circulation 1963, 28, 767.

10. Baer, D. M., and J. J. Osborn. The postperfusion pulmonary congestion syndrome. Amer. J. clin. Path. 1960, 34, 442.

11. Finley, T. N., C. Lenfant, P. Haab, J. Piiper, and H. Rahn. Venous admixture in the pulmonary circulation of anesthetized dogs. J. appl. Physiol. 1960, $15,418$.

12. Fritts, H. W., Jr., A. Hardewig, D. F. Rochester, J. Durand, and A. Cournand. Estimation of pulmonary arteriovenous shunt-flow using intravenous injections of $\mathrm{T}-1824$ dye and $\mathrm{Kr}^{85}$. J. clin. Invest. 1960, 39, 1841.

13. Aviado, D. M., M. de Burgh Daly, C. Y. Lee, and C. F. Schmidt. The contribution of the bronchial circulation to the venous admixture in pulmonary venous blood. J. Physiol. (Lond.) 1961, 155, 602.

14. Farhi, L. E., and H. Rahn. A theoretical analysis of the alveolar-arterial oxygen difference with special reference to the distribution effect. J. appl. Physiol. 1955, 7, 699.

15. Guyton, A. C. Circulatory Physiology: Cardiac Output and Its Regulation. Philadelphia, W. B. Saunders, 1963, p. 47.

16. Scannell, J. G., A. E. Baue, and H. C. Urschel, Jr. Re-operation for failed mitral valvulotomy. Ann. Surg. 1963, 158, 884.

17. Scannell, J. G., R. S. Shaw, J. F. Burke, W. G. Austen, and J. S. Saurbrey. Operative treatment of aortic stenosis in the adult. Circulation 1963, 27, 772.

18. Starr, A., M. L. Edwards, C. W. McCord, and H. E. Griswold. Aortic replacement: clinical experience with semirigid ball-valve prosthesis. Circulation 1963, 27, 779.

19. Starr, A., M. L. Edwards, and H. Griswold. Mitral replacement: late results with a ball valve prosthesis. Progr. cardiovasc. Dis. 1962, 5, 298.

20. Scholander, P. F. Analyzer for accurate estimation of respiratory gases in one-half cubic centimeter samples. J. biol. Chem. 1947, 167, 235.

21. Severinghaus, J. W., and A. F. Bradley. Electrodes for blood $\mathrm{P}_{\mathrm{O}_{2}}$ and $\mathrm{P}_{\mathrm{CO}_{2}}$ determination. J. appl. Physiol. 1958, 13, 515. 
22. Clark, L. C., Jr. Monitor and control of blood and tissue oxygen tensions. Trans. Amer. Soc. artificial internal Organs 1956, 2, 41.

23. Van Slyke, D. D., and J. M. Neill. The determination of gases in blood and other solutions by vacuum extraction and manometric measurement. J. biol. Chem. 1924, 61, 523.

24. Sendroy, J., R. T. Dillon, and D. D. Van Slyke. Studies of gas and electrolyte equilibria in blood. XIX. The solubility and physical state of uncombined oxygen in blood. J. biol. Chem. 1934, 105, 597.

25. Hedley-Whyte, J., and M. B. Laver. $\mathrm{O}_{2}$ solubility in blood and temperature correction factors for $\mathrm{Po}_{2}$. J. appl. Physiol. 1964, 19, 901.

26. Riley, R. L., and A. Cournand. Analysis of factors affecting partial pressures of oxygen and $\mathrm{CO}_{2}$ in gas and blood of lungs: theory. J. appl. Physiol. 1951, 4, 77.

27. Ayres, S. M., A. Criscitiello, and E. Grabovsky. Components of alveolar-arterial $\mathrm{O}_{2}$ difference in normal man. J. appl. Physiol. 1964, 19, 43.

28. Lambertsen, C. J., P. L. Bunce, D. L. Drabkin, and C. F. Schmidt. Relationship of oxygen tension to hemoglobin oxygen saturation in the arterial blood of normal men. J. appl. Physiol. 1952, 4, 873.

29. Laver, M. B., and A. Seifen. Sauerstofftransport, Erythrocytenkonservierung und extrakorporale Zirkulation. Anaesthesist 1964, 13, 110.

30. Dill, D. B. in Handbook of Respiration. Philadelphia, W. B. Saunders, 1958, p. 73.
31. Rahn, H., and W. O. Fenn. A Graphical Analysis of the Respiratory Gas Exchange. The $\mathrm{O}_{2}-\mathrm{CO}_{2}$ Diagram. Washington, D. C., Amer. Physiol. Soc., 1955.

32. Bishop, J. M., P. Harris, M. Bateman, and J. M. Raine. Respiratory gas exchange in mitral stenosis at three levels of inspired oxygen before and after the infusion of acetylcholine. Clin. Sci. 1962, 22, 53.

33. Bendixen, H. H., J. Hedley-Whyte, and M. B. Laver. Impaired oxygenation in surgical patients during general anesthesia with controlled ventilation. A concept of atelectasis. New Engl. J. Med. 1963, 269, 991.

34. Hedley-Whyte, J., M. B. Laver, and H. H. Bendixen. Effect of changes in tidal ventilation on physiologic shunting. Amer. J. Physiol. 1964, 206, 891.

35. Bendixen, H. H., G. M. Smith, and J. Mead. Pattern of ventilation in young adults. J. appl. Physiol. 1964, 19, 195.

36. Laver, M. B., J. Morgan, H. H. Bendixen, and E. P. Radford, Jr. Lung volume, compliance, and arterial oxygen tensions during controlled ventilation. J. appl. Physiol. 1964, 19, 725.

37. Egbert, L. D., and H. H. Bendixen. Effect of morphine on breathing pattern. A possible factor in atelectasis. J. Amer. med. Ass. 1964, 188, 485.

38. Sackur, P. Weiteres zur Lehre vom Pneumothorax. Virchows Arch. path. Anat. 1897, 150, 151.

39 Ostle, B. Statistics in Research. Ames, Iowa State College Press, 1954. 